\title{
ASSESSMENT OF FERTILITY POTENTIAL INDEX OF SOME SOILS OF MOHESHKHALI BETEL LEAF (Piper betle L.) ESTATE
}

\author{
Chowdhury, S., D. Chakraborty and M. K. Rahman \\ Department of Soil, Water and Environment, University of Dhaka, Dhaka-1000, Bangladesh
}

\begin{abstract}
Fifteen soil samples $(0-15 \mathrm{~cm}$ depth) and fifteen betel leaf samples from Bara Moheshkhali, Choto Moheshkhali, Hoanak, Kalmarchora, Shaplapur union of Moheshkhali upazila, Cox's Bazar district were collected on December-January (2020-2021). It was collected for the purpose of evaluating the color, particle density, moisture content, texture, $\mathrm{pH}, \mathrm{EC}$ and organic matter content of soils and total nitrogen, phosphorous, potassium and sulfur of the soils and total protein content, nitrogen, phosphorus, potassium and sulfur of leaves. Maximum sampled soil was containing yellowish red color when moist and showed brown color when dried. Some of them were flood plain soil and that's why showed grey color during dry and moist condition. Mean particle density was $2.49 \mathrm{~g} / \mathrm{cm} 3$ and mean moisture content was $13.95 \%$. Average sand, silt and clay were $65.08 \%, 18.56 \%$ and $19.26 \%$, respectively. The texture of the soils was sandy loam to clay loam. The sand was by far the dominant fraction in the soils. Mean $\mathrm{pH}$ value was 5.63, organic matter was $0.30 \%$ and EC was $99.38 \mu \mathrm{S} / \mathrm{cm}$. Mean total nitrogen, phosphorus, potassium and sulfur of the soils were $0.04,0.46,0.25$ and $0.26 \%$, respectively. The mean concentration of protein, nitrogen, phosphorus, potassium and sulfur in the betel leaf samples were $20.56,3.29,0.39,0.79$ and $0.20 \%$, respectively. This investigation focuses on the fertility status and physico-chemical properties of soil in betel leaf garden of only hilly island of Bangladesh, Moheshkhali.
\end{abstract}

Key words: Assessment; Fertility index; Moheshkhali; Betel leaf.

\section{INTRODUCTION}

Moheshkhali is an upazila of Cox's Bazar district in the division of Chittagong, Bangladesh and located at $21.5500^{\circ} \mathrm{N}$ and $91.9500^{\circ} \mathrm{E}$. It has a total area of $362.18 \mathrm{~km}^{2}$. It is the only hilly island of Bangladesh. This island is blessed with various types of natural resources including fertile soil. High ground and especially fertile soil are best for betel (Sripradha 2014), the hilly region of Moheshkhali is a perfect place for betel leaf cultivating. In fact, Moheshkhali is famous for its sweetened betel leaf. The island has a moist tropical climate with a long wet season (April-October) and a relatively short dry season (November-March). The mean annual precipitation, temperature, and relative humidity are 3,627 $\mathrm{mm}, 25.7^{\circ} \mathrm{C}$, and 70 to $90 \%$, respectively (Baul et al. 2020). This region is prone to cyclonic storms that occur during April-May and October-November (Baul et al. 2020).

The island has four subdivisions including active, young and old coastal plain, and hilly areas with piedmont plain. The geological deposition of sedimentation forms landmasses (Majlis 2013). The hilly areas of Moheshkhali have forest covers where several hills reach up to $23 \mathrm{~m}$ and there are low-lying valleys. Usually betel leaves are cultivated in these areas. The soil of these areas varies from clay to sandy loam and to some extent yellowish red sandy clay, with low $\mathrm{pH}$. Hills are mainly composed of sands and various stones, including limestone, siltstone, and mudstone (DoE 1999).

Betel vine (Piper betle L.) belongs to the family Piperaceae, i.e. the Black Pepper family. Betel leaf is cultivated in a garden locally called "baroj". The vine is raised by vegetative propagation from the cutting under partially shaded and humid environment inside the baroj (Guha 2006). The baroj is covered with bamboo sticks and chan leaf (sun-grass). A sun-grass fence is used over the garden works as a greenhouse to supply optimum temperature, to keep the soil moist and to protect the leaves from over drying, excess rainfall, birds and dusts. The betel leaf needs soil with balanced $\mathrm{pH}$. The soil is plowed in furrows. The furrows are usually 10 to 15 -meter length, 75 centimeters in width and 75 
centimeters in depth. Usually farmers apply khail (oil cakes), cow manure, wood ash are applied on the top soil. It is usually planted at the start of the monsoon season. It needs proper shade and irrigation to grow well. The betel leaf is usually cultivated in hilly area or comparatively upper land where good drainage is present (Das and Mohanty 2016). Betel leaf cannot sustain water logged condition. Moderate air circulation is also important because it keeps the baroj insect-free. Bamboo sticks are used to provide support to the vines. Three to six months after cultivation, when the vines reach 150-180 centimeters, the harvesting begins. If properly taken care of a betel leaf garden can produce leaf for over 6 years long.

According to Jana (1996), Khoshoo et al. (1981), Samanta (1994) and Sharma (1996), this edible leaf has achieved an esteemed position in the human society right from the dawn of civilization, particularly in the countries like Bangladesh, Burma, China, India, Indonesia, Malaysia, Nepal, Pakistan, Philippines, South Africa, Sri Lanka, Thailand etc., where leaves are traditionally used for chewing with many other ingredients like sliced areca nut, slaked lime, coriander, aniseed, clove, cardamom, sweetener, coconut scrapings, ashes of diamond, pearl, gold and silver (Ayurvedic preparations), jelly, pepper mint, flavouring agent, fruit pulp etc. (CSIR 1996). Betel quid is regarded as an excellent mouth freshener and mild vitalize (Aishwarya et al. 2016).

Piper betel leaves are well-off in moisture, protein, fats, minerals, vitamins and in phytochemical and also antioxidants. It helps in curing and treatment of various diseases like halitosis, boils and abscesses, conjunctivitis, constipation, headache, hysteria, itches, mastitis, mastoiditis, leucorrhoea, otorrhoea, ringworm, swelling of gum, rheumatism, abrasion, cuts and injuries etc. (Shukla et al. 2015).

The hilly areas of Moheshkhali are fertile enough for cultivating betel leaf. Soil health deterioration is a common phenomenon for betel gardens in Bangladesh. This investigation focuses on the fertility status and physico-chemical properties of soil in the betel leaf garden of Moheshkhali. This study will definitely give an idea about betel leaf and its related soil which can be of great help in assessing soil fertility program for betel leaf growing areas in the country.

\section{Collection and processing of soil and leaf samples}

\section{MATERIAL AND METHODS}

Fifteen soil samples $(0-15 \mathrm{~cm}$ depth) were collected after removing surface litter from fifteen different spots of Moheshkhali hilly region of Bangladesh in Dec-Jan 2020-21. The spots were Spot 1: Adharghona; Spot 2: Dhoisshyakhata; Spot 3: Dhapua; Spot 4: Debangapara 1; Spot 5: Borchora; Spot 6: Monipur; Spot 7: Uttarpara; Spot 8: Bottoli; Spot 9: Adinath temple; Spot 10: Panirchora; Spot 11: Kydabad; Spot 12: Hindu Para; Spot 13: Lombaghona; Spot 14: Timibazar; and Spot 15: Debangapara 2. Then these samples were labeled and carried properly in eco-friendly jute bags to the laboratory for analysis. These samples were placed on trays and air-dried. After drying, the lump of collected soil was broken using pestle and mortar, and sieved using $2 \mathrm{~mm}$ sieve. After that, the samples were kept in a piece of brown paper with proper labeling. Fifteen betel plants were chosen from the above spots for leaf testing. An overview of six months old betel leaf garden is presented in Fig. 1. Fifteen young leaf samples (deep green) were collected from the top of the plants wiped with soft white clothes, air-dried, oven-dried and powdered in a mechanical grinder and kept in brown paper envelops with appropriate labeling for chemical analysis in the laboratory of the Department of Soil, Water and Environment at the University of Dhaka. 


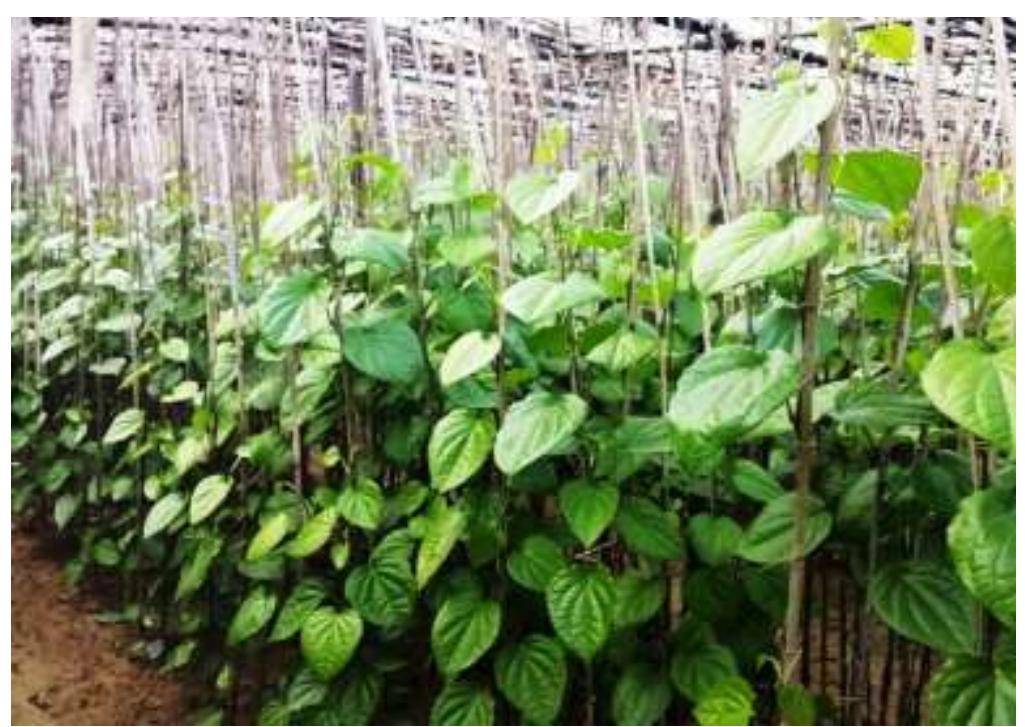

Fig.1. A view of six month old cultivated betel leaf in a commercial garden.

\section{Physico-chemical properties analysis of soils}

Soil moisture content was determined by the Gravimetric method (Miller and Donahue 1965). The collected soil samples were taken to the laboratory, and later oven dried at $100^{\circ} \mathrm{C}$ for 24 hours. The oven dry weight was then subtracted from the initial weight and the values expressed as percentages. The matrix colour of soil was evaluated by visual examination in outdoor sunlight with the Munsell colour chart. Soil particle density was determined by the Pycnometer method (Black 1965). The particle size analysis of the soils was done by the Hydrometer method and textural classes were determined by Marshall's triangle coordinate curve (Bouyoucos 1962). The $\mathrm{pH}$ of the soil samples was determined in the laboratory by mixing soil with distilled water in the ratio of 1:2.5. The resulting suspension was then shaken for half an hour and then allowed to stand for one hour and measured by using a $\mathrm{pH}$ meter at $25^{\circ} \mathrm{C}$ (Jackson 1958). The electrical conductance (EC) was measured by using a digital conductivity meter (Richards 1954). Fifteen grams of soil sample were mixed with $30 \mathrm{ml}$ of distilled water and then the suspension was filtered through Whatman No.1 filter paper. The filtrate was then stirred intermittently and then allowed to stand for 30 minutes for the complete dissolution of soluble salts. The soil water mixture was again allowed to stand so that soil settled down. Finally, electrical conductance was recorded by inserting conductivity cell in it. The organic carbon content of soils was determined by the Wet Oxidation method (Walkley and Black 1934). The organic matter was calculated by multiplying the percent organic carbon with the Van Bemmelen factor 1.72. For nitrogen, $2 \mathrm{~g}$ of soil sample were digested in a Kjeldahl digestion flask (Marr and Cresser 1983); for potassium, sulfur and phosphorus $2 \mathrm{~g}$ of soil sample were digested with nitric-perchloric acid. The phosphorus of the digest was determined by vanadomolybdophosphoric yellow color method at $430 \mathrm{~nm}$ using a spectrophotometer (model DR 5000) (Olsen et al. 1954). The potassium of the digest was determined by using JENWAY flame photometer (model PFP 7) (Pratt 1965). The sulfur of the digest was determined by using turbidimetric method (Bardsley and Lancaster 1965).

\section{The nutrient content and protein content in leaf}

For nitrogen, 0.2g of leaf sample was digested in a Kjeldahl digestion flask (Marr and Cresser 1983); for potassium, sulfur and phosphorus, $0.2 \mathrm{~g}$ of leaf sample was digested with nitric-perchloric acid. The phosphorus of the digest was determined by the vanadomolybdophosphoric yellow color method at 430nm using a spectrophotometer (model DR 5000) (Olsen et al. 1954). The potassium of the digest was 
determined by using JENWAY flame photometer (model PFP 7) (Pratt 1965). The sulfur of the digest was determined by using the turbidimetric method (Bardsley and Lancaster 1965). The protein contents were determined by multiplying a factor of 6.25 with nitrogen contents (Magomaya et al. 2014).

Statistical analysis: All statistical analyses were calculated using Minitab, version 17.

\section{RESULTS AND DISCUSSION}

\section{Morphological, physical and chemical properties}

The matrix colour of the soils was found to be a mixture of brown, red, yellowish brown and gray. Moisture content ranged from 4.23-21.39\% with an average of $13.95 \%$. Soil moisture has a profound effect on soil microbial activity which in turn enhances soil organic carbon content (Liu et al. 2009). The particle density of the soil sample ranged from $2.15-2.95 \mathrm{~g} / \mathrm{cm}^{3}$ with an average of $2.49 \mathrm{~g} / \mathrm{cm}^{3}$. Soil texture may affect productivity in a variety of ways, i.e. by affecting moisture availability, soil temperature, nutrient supply and the accessibility of soil organic matter to microbial decomposition (Schimel et al. 1996). The soil texture of the samples from betel garden in Moheshkhali is sandy loam to clay loam (Table 1), which may favour betel leaf plantation.

There were variations in soil $\mathrm{pH}$ levels from the soil samples analyzed. Average $\mathrm{pH}$ of the soil samples was 5.63 which is moderately acidic (Table 2). The $\mathrm{pH}$ ranged from 5.24-6.17. A well-drained fertile sandy or sandy loam or sandy clay soil with $\mathrm{pH}$ range of $5.6-8.2$ is considered suitable for betel cultivation (CSIR 1996, Guha and Jain 1997). Electrical conductivity (EC) is a measurement that correlates with soil properties that affect productivity including soil texture, cation exchange capacity, drainage conditions, organic matter level, salinity and subsoil characteristics. Electrical conductivity ranges from 35.10 to $269 \mu \mathrm{S} / \mathrm{cm}$ with an average of $99.38 \mu \mathrm{S} / \mathrm{cm}$. Soil acidity affects crop growth in two ways: directly by acidity effect and indirectly by affecting nutrient availability (Hasan et al. 2020).

Table 1. Physical properties of some soils of Betel Leaf Garden, Moheshkhali, Chittagong, Bangladesh.

\begin{tabular}{|c|c|c|c|c|c|c|c|c|c|c|}
\hline Location & $\begin{array}{l}\text { Moisture } \\
\text { content } \\
(\%)\end{array}$ & Colour & Colour name & $\begin{array}{l}\text { Particle } \\
\text { density } \\
(\text { gcm-3) }\end{array}$ & $\begin{array}{l}\% \\
\text { Sand }\end{array}$ & $\begin{array}{l}\% \\
\text { Slit }\end{array}$ & $\begin{array}{l}\% \\
\text { Clay }\end{array}$ & $\begin{array}{l}\text { Textural } \\
\text { Class }\end{array}$ & $\begin{array}{l}\text { Sand/ } \\
\text { Silt } \\
\text { Ratio }\end{array}$ & $\begin{array}{l}\text { Silt/ } \\
\text { Clay } \\
\text { Ratio }\end{array}$ \\
\hline Adharghona & 21.18 & $5 Y R 5 / 6$ & Yellowish red & 2.57 & 64 & 20 & 16 & Sandy loam & 3.2 & 1.25 \\
\hline Dhoisshyakhata & 12.15 & 5YR 5/6 & Yellowish red & 2.55 & 48.5 & 30 & 21.5 & Loam & 1.62 & 1.39 \\
\hline Dhapua & 17.47 & 10YR 6/3 & Pale brown & 2.59 & 88.5 & 2.5 & 9 & Loamy sand & 35.4 & 0.27 \\
\hline Debangapara 1 & 6.26 & $5 Y R 5 / 6$ & Yellowish red & 2.61 & 61 & 25 & 14 & Sandy loam & 2.44 & 1.78 \\
\hline Borchora & 13.27 & 10YR 6/3 & Pale brown & 2.2 & 88.5 & 2.5 & 9 & Loamy sand & 35.4 & 0.27 \\
\hline Monipur & 13.13 & $5 Y R$ 5/6 & Yellowish red & 2.62 & 63.5 & 15 & 21.5 & Sandy clay loam & 4.23 & 0.69 \\
\hline Uttarpara & 17.16 & $5 Y R$ 5/6 & Yellowish red & 2.33 & 43.5 & 32.5 & 24 & Loam & 1.34 & 1.35 \\
\hline Bottoli & 8.65 & $5 Y R$ 5/6 & Yellowish red & 2.53 & 41 & 37.5 & 21.5 & Loam & 1.09 & 1.74 \\
\hline Adinath temple & 14.36 & $5 Y R$ 5/6 & Yellowish red & 2.95 & 59 & 20 & 21.5 & Sandy clay loam & 2.95 & 0.93 \\
\hline Panirchora & 21.39 & $5 Y R$ 5/6 & Yellowish red & 2.22 & 78.5 & 5.5 & 16 & Sandy loam & 14.27 & 0.34 \\
\hline Kydabad & 15.11 & $5 Y R$ 5/6 & Yellowish red & 2.37 & 55 & 23.5 & 21.5 & Sandy clay loam & 2.34 & 1.09 \\
\hline Hindu Para & 12.69 & 5YR 5/6 & Yellowish red & 2.61 & 71 & 7.5 & 21.5 & Sandy clay loam & 9.47 & 0.35 \\
\hline Lombaghona & 12.92 & $5 Y R$ 5/6 & Yellowish red & 2.7 & 71 & 21 & 24 & Sandy loam & 3.38 & 0.88 \\
\hline Timibazar & 19.21 & $5 Y R$ 5/6 & Yellowish red & 2.45 & 77.5 & 1 & 21.5 & Sandy clay loam & 77.5 & 0.05 \\
\hline Debangapara 2 & 4.23 & $5 Y R$ 5/6 & Yellowish red & 2.15 & 38.5 & 35 & 26.5 & Clay loam & 1.1 & 1.32 \\
\hline Mean & 13.95 & - & - & 2.49 & 65.08 & 18.56 & 19.26 & - & 13.05 & 0.91 \\
\hline
\end{tabular}

\section{Nutrient status of soil and betel leaf}

Nutrient analysis of the soil samples showed that total nitrogen content ranged from $0.02-0.06 \%$ with an average of $0.04 \%$. Total phosphorus content was from $0.19 \%$ to $0.93 \%$ with an average of $0.64 \%$. Total potassium content of the soil samples ranged from $0.02 \%$ to $0.78 \%$ where the average content was 
$0.25 \%$. Total sulfur content was from $0.16 \%$ to $0.39 \%$ with an average of $0.26 \%$. These values are presented in Table 2 . Results varied significantly at $0.05 \%$ level. The nutrient status was low. It might happen due to acidity and uptaking nutrients by betel vine.

The percentage of organic matter ranged from $0.05 \%$ to $0.69 \%$ with an average of $0.3 \%$. Organic matter content in Bangladesh soils is generally around $1 \%$ in most and around $2 \%$ in few soils (Islam 2008). The carbon status of Bangladesh soils is not only poor, but also decreasing day by day. The depletion of soil organic matter was from 9 to $46 \%$ in different regions of Bangladesh over the last 20 years from1970 to 1990 (Miah 1993). Soil organic matter mineralization and release substantial quantity of N, P, S and very important of micronutrients (Hasan et al. 2020).

The price and test of betel leaf are determined by its quality. The chemical composition of betel leaf is influenced by soil and environmental characteristics of the betel garden. The nutrient analysis of leaf samples showed that the nitrogen content ranged from $2.27 \%$ to $4.64 \%$ with an average of $3.29 \%$. Phosphorus content ranged from $0.06 \%$ to $0.82 \%$ with an average of $0.39 \%$. Potassium content ranged from $0.24 \%-1.25 \%$ with an average of $0.79 \%$. Sulfur content ranged from $0.1 \%$ to $0.32 \%$. The mean Sulfur content in the leaf was $0.20 \%$. These values are presented in Table 3 . Results varied significantly $(\mathrm{p} \leq 0.05)$. Phosphorus plays important role in all crop biochemical process; viz. photosynthesis, respiration, energy storage and transfer, cell division, cell enlargement and nitrogen fixation. Potassium is associated with the movement of water, nutrients and carbohydrates in plant tissue. It is involved with enzyme activation within the plants which affect protein, starch and ATP production (Hasan et al. 2020).

Table 2. pH, organic matter, total nitrogen, phosphorus, potassium and sulfur of some soils of Moheshkhali betel garden, Chittagong, Bangladesh.

\begin{tabular}{lccccccc}
\hline Location & $\mathbf{p H}$ & $\begin{array}{c}\text { EC } \\
(\boldsymbol{\mu S} / \mathbf{c m})\end{array}$ & $\begin{array}{c}\text { Organic matter } \\
(\boldsymbol{\%})\end{array}$ & $\begin{array}{c}\text { Nitrogen } \\
(\boldsymbol{\%})\end{array}$ & $\begin{array}{c}\text { Phosphorus } \\
(\boldsymbol{\%})\end{array}$ & $\begin{array}{c}\text { Potassium } \\
(\boldsymbol{\%})\end{array}$ & $\begin{array}{c}\text { Sulphur } \\
(\boldsymbol{\%})\end{array}$ \\
\hline Adharghona & 5.27 & 98.4 & $0.57 \%$ & 0.04 & 0.51 & 0.04 & 0.29 \\
Dhoisshyakhata & 5.48 & 111.6 & $0.34 \%$ & 0.07 & 0.27 & 0.39 & 0.37 \\
Dhapua & 6.17 & 43 & $0.22 \%$ & 0.03 & 0.46 & 0.27 & 0.16 \\
Debangapara 1 & 5.81 & 75.2 & $0.05 \%$ & 0.06 & 0.53 & 0.29 & 0.32 \\
Borchora & 5.45 & 54.7 & $0.05 \%$ & 0.02 & 0.19 & 0.14 & 0.27 \\
Monipur & 6.01 & 63.2 & $0.23 \%$ & 0.02 & 0.4 & 0.02 & 0.26 \\
Uttarpara & 5.54 & 50.2 & $0.36 \%$ & 0.03 & 0.93 & 0.16 & 0.2 \\
Bottoli & 5.24 & 126.7 & $0.04 \%$ & 0.03 & 0.38 & 0.19 & 0.39 \\
Adinath temple & 5.89 & 67.1 & $0.49 \%$ & 0.03 & 0.38 & 0.06 & 0.26 \\
Panirchora & 5.7 & 269 & $0.36 \%$ & 0.05 & 0.64 & 0.35 & 0.18 \\
Kydabad & 5.63 & 68.9 & $0.26 \%$ & 0.03 & 0.35 & 0.34 & 0.33 \\
Hindu Para & 5.85 & 38.6 & $0.13 \%$ & 0.03 & 0.32 & 0.21 & 0.04 \\
Lombaghona & 5.3 & 234 & $0.35 \%$ & 0.04 & 0.53 & 0.43 & 0.26 \\
Timibazar & 5.39 & 155.1 & $0.69 \%$ & 0.04 & 0.79 & 0.02 & 0.32 \\
Debangapara 2 & 5.71 & 35.1 & $0.35 \%$ & 0.05 & 0.24 & 0.78 & 0.25 \\
\hline Mean & $\mathbf{5 . 6 3}$ & $\mathbf{9 9 . 3 8}$ & $\mathbf{0 . 3 0 \%}$ & $\mathbf{0 . 0 4}$ & $\mathbf{0 . 4 6}$ & $\mathbf{0 . 2 5}$ & $\mathbf{0 . 2 6}$ \\
\hline LSD 5\% & $\mathbf{N S}$ & $\mathbf{N S}$ & $\mathbf{0 . 0 0 1}$ & $\mathbf{0 . 0 0 3}$ & $\mathbf{0 . 0 3}$ & $\mathbf{0 . 0 1}$ & $\mathbf{0 . 0 1}$ \\
\hline
\end{tabular}

Islam et al. (2020) reported that the maximum and minimum amount of protein were obtained in

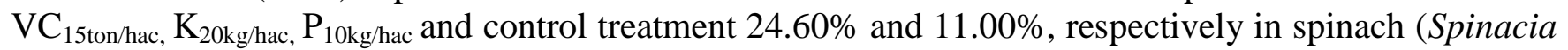
oleracea) leaf. The protein content ranges from $14.19 \%$ to $29 \%$ with $20.56 \%$ average value.

\section{Fertility status of Moheshkhali soil}

Moheshkhali soil is included in AEZ (Agro Ecological Zone) 23. The fertility status of AEZ 23 ranges from very low to optimum (Table 4). 
Table 3. Nutrients concentration in the betel leaves of Moheshkhali.

\begin{tabular}{|c|c|c|c|c|c|}
\hline Location & Protein Content (\%) & Nitrogen (\%) & Phosphorus (\%) & Potassium (\%) & Sulphur (\%) \\
\hline Dhoisshyakhata & 17.19 & 2.75 & 0.27 & 0.24 & 0.2 \\
\hline Dhapua & 23.44 & 3.75 & 0.43 & 0.78 & 0.18 \\
\hline Debangapara1 & 25.5 & 4.08 & 0.72 & 0.85 & 0.26 \\
\hline Borchora & 29 & 4.64 & 0.27 & 0.95 & 0.06 \\
\hline Monipur & 21.94 & 3.51 & 0.38 & 0.7 & 0.1 \\
\hline Uttarpara & 22.63 & 3.62 & 0.43 & 1.25 & 0.18 \\
\hline Bottoli & 19.94 & 3.19 & 0.48 & 0.83 & 0.22 \\
\hline Adinath temple & 22.06 & 3.53 & 0.38 & 0.8 & 0.32 \\
\hline Panirchora & 20.88 & 3.34 & 0.82 & 0.97 & 0.17 \\
\hline Kydabad & 19.75 & 3.16 & 0.45 & 0.95 & 0.29 \\
\hline Hindu Para & 15.75 & 2.52 & 0.17 & 0.24 & 0.25 \\
\hline Lombaghona & 14.19 & 2.27 & 0.09 & 0.34 & 0.27 \\
\hline Timibazar & 21.38 & 3.42 & 0.46 & 1.09 & 0.12 \\
\hline Debangapara2 & 17.06 & 2.73 & 0.06 & 1.3 & 0.14 \\
\hline Mean & 20.56 & 3.29 & 0.39 & 0.79 & 0.2 \\
\hline LSD at $5 \%$ & NS & 0.01 & 0.01 & 0.01 & 0.03 \\
\hline
\end{tabular}

The yield and quality of betel leaf can be increased by proper nutrient management. Moreover, nutrient availability throughout the crop growth period from the applied sources has considerable importance (Fahim et al. 2017).

Table 4. Soil fertility status of AEZ 23 (BARC 2018).

\begin{tabular}{llllllllllll}
\hline Major land type & Soil pH & $\begin{array}{l}\text { Soil organic } \\
\text { matter }\end{array}$ & N & P & K & S & Ca & Mg & Zn & B & Mo \\
\hline High land & $3.9-6.2$ & L-M & VL-L & VL-L & L-M & L-M & M-Opt & M-Opt & L-M & L-M & M \\
Medium high land & $4.4-6.2$ & L-M & VL-L & VL-L & L-M & L-M & M-Opt & M-Opt & L-M & L-M & M \\
Medium low land & $4.5-6.2$ & L-M & VL-L & VL-L & L-M & L-M & M-Opt & M-Opt & L-M & L-M & M \\
\hline
\end{tabular}

Though the soils had enough organic matter, but nutrient status was lower than that of the critical value. Integrated nutrient management (INM) is always advantageous from a long-term perspective both in terms of cost of production and soil health (Debanath et al. 1985). This study is expected to furnish valuable clues to upgrade productivity through a fair utilization of mineral and organic fertilizers to improve the stock of the plant nutrient in soil to sustain profitable production of betel leaf.

\section{REFERENCES}

Aishwarya, J., E. S. Chauhan, A. Singh and A. Tiwari. 2016. A Review: Nutraceutical properties of Piper betel (paan). Am. J. Phytomed. Clinic. Therapeutics. 4(2): 28-41.

BARC (Bangladesh Agricultural Research Council). 2018. Fertilizer Recommendation Guide. Soil publication no. 45. Bangladesh Agricultural Research Council, Farm gate, Dhaka 27, Bangladesh.

Bardsley, C. E. and J. D. Lancaster. 1965. Sulfur. In: C. A. Black (ed.). Methods of Soil Analysis. American Society of Agronomy, Inc., Madison, Wisconsin, USA., pp. 1102-1114.

Baul, T. K., A. Chakraborty, R. Nandi, A. Kilpelainen and T. Sultana. 2020. Effects of Tree Species Diversity and Stand Structure on Carbon Stocks of Homestead Forests in Moheshkhali Island, Southern Bangladesh. Research square. 5 pp.

Black, C. A. 1965. Methods of Soil Analysis Part 2. American Society of Agronomy, Madison, Wisconsin, USA., pp. 374-399. 
Bouyoucos, G. T. 1962. Hydrometer method improved for making particle size analysis of soils. Agronomy Journal. 54: 461-465.

CSIR (Council of Scientific and Industrial Research, New Delhi) 1996. The Wealth of India. 8: 84-94.

Das, S. and S. Mohanty. 2016. Biotechnological intervention in betelvine (Piper betle L.): A review on recent advances and future prospects. Asia Pacific J. Trop. Medi. 9(10): 938-946.

Debanath, P. K., K. Sengupta, C. Sengupta and B. N. Chatterjee. 1985. Indian Farming. 25(7): 22-23.

DoE (Department of Environment). 1999. GIS and Cartographic Services - Final Report, PreInvestment Facility Study: Coastal and Wetland Biodiversity Management Project (Project $B G D / 94 / G 41)$, Dhaka, Bangladesh.

Fahim, A. H. F., M. S. Naher, M. A. Wadud, R. Sarker and M. J. Alam. 2017. Impact of nutrient management on yield and quality of betel leaf. J. Scientific Achieve. 2(3): 13-18.

Guha, P. and R. K. Jain. 1997. Status Report on Production, Processing and Marketing of Betel Leaf (Piper betle L.). Agricultural and Food Engineering Department, IIT, Kharagpur, India.

Guha, P. 2006. Betel leaf: The neglected Green Gold of India. J. Human Ecol. 19(2): 87-93.

Hasan, M. N., M. A. Bari, M. L. Rahman and B. K. Bhander. 2020. Soil Fertility Trend in Bangladesh 2010 to 2020. Soil Resource Development Institute, Ministry of Agriculture, Bangladesh.

Islam, M. S. 2008. Soil fertility history, present status and future scenario in Bangladesh. Bangladesh J. Agri. Environ. 4(Special Issue): 129-151.

Islam, M. M., S. M. Akhter, S. A. Sujon, M. Akarim and M. K. Rhaman 2020. Effect of vermicompost and $\mathrm{P}, \mathrm{K}$ on growth and protein content of spinach (Spinacia oleracea). Bangladesh J. Bot. 49: 141146.

Jackson, M. L. 1958. Soil Chemical Analysis. Prentice-Hall, Inc., Englewood Cliff, NJ, USA. 498 pp.

Jana, B. L. 1996. Improved technology for betel leaf cultivation. In: "Seminar-cum-Workshop on Betel leaf Marketing”, held at State cashew nut farm, Directorate of Agricultural Marketing, Digha, Midnapore (W. B.), India.

Khoshoo, T. N., S. D. Khanduja and V. R. Balasubrahmanyam. 1981. In: Proc. of Group Discussion on Improvement of Betelvine Cultivation. National Botanical Research Institute, Lucknow, India., pp. 107-110.

Liu, W., Z. Zhang and S. Wan. 2009. Predominant role of water in regulating soil and microbial respiration and their responses to climate change in semiarid grassland. Global Change Biology. 15: 184-195.

Marr, I. L. and M. S. Cresser. 1983. The lithosphere. In: Environmental Chemical Analysis. Blackie and Son, UK., pp.155- 182.

Majlis, A. B., M. M. A. Islam, M. Khasru and K. Ahsan. 2013. Protected to open basin depositional system: An Appraisal for the Quaternary Evolution of the Moheshkhali-Kutubdia Coastal Plain, Bangladesh. Bangladesh J. Geol. 26: 64-77.

Magomaya, A. M., D. Kubmarawa, J. A. Ndahi and G. G. Yebpella. 2014. Determination of plant proteins via the Kjeldahl method and amino acid analysis: A comparative study. Int. J. Scientific Technol. Res. 3(4): 68-72. 
Miah, M. M. U. 1993. Integrated nutrient management system for sustainable agricultural production in Bangladesh. Paper presented in the training course on Unified Methodology for Integrated Nutrient Management at Bangladesh Rice Research Institute (BRRI), Gazipur, Bangladesh on 10-16 July 1993.

Miller, W. R. and L. R. Donahue. 1965. An Introduction to Soils and Plant Growth. Vol. 6. Pretence Hall ltd., London, UK. 632 pp.

Olsen, S. R., C. V. Cole, F. S. Watanabe and L. A. Dean. 1954. Estimation of available phosphorus in soils by extraction with sodium bicarbonate. US Department of Agriculture Circular No. 939.

Pratt, P. S. 1965. Potassium. In: C. A. Black (ed.). Methods of Soil Analysis. Part 2. American Society of Agronomy, Inc., Madison, Wisconsin, USA., pp. 1022-1030.

Richards, L. A. (ed.) 1954. Diagnosis and improvement of saline and alkali soil. In: USDA Handbook No.60. US Govt. Print Office, Washington, USA., pp. 84-156.

Samanta, C. 1994. Paan chaser samasyabali-o-samadhan: Ekti samikkha (In Bengali): A Report on the Problems and Solutions of Betel Vine Cultivation. A booklet published by Mr. H. R. Adhikari, C2/16, Karunamoyee, Salt Lake City, Kolkata-64 (WB), India.

Schimel, D. S., B. H. Barswell, R. Mckeown, D. S. Ojima, W. J. Parton and W. Pulliam. 1996. Climate and nitrogen controls on the geography and time scales of terrestrial biogeochemical cycling. Global Biogeochemical Cycles. 10: 677-692.

Sharma, M. L., A. K. S. Rawat, R. K. Khanna, A. R. Chowdhury and R. M. Raina. 1996. Flavour characteristics of betel leaves. Euro Cosmetics. 5: 22-24.

Shukla, R., S. Sachan, A. Mishra and A. Kumar. 2015. A scientific review on commonly chewing plants of Asians: Piper betel Linn. J. Harmonized Res. Pharm. 4(1): 1-10

Sripradha, S. 2014. Betel leaf - The green gold. J. Pharmaceutical Sci. Res. 6(1): 36-37.

Walkley, A. and I. A. Black. 1934. An experiment of the Degtjareff method for determining soil organic matter and a proposed modification of the chromic acid titration method. Soil Science. 37: 29-38. 